\title{
Key Lecture: "Lyric poetry as seen from an interdisciplinary perspective"
}

\author{
Gabriele ZIETHEN \\ Worms / Germany
}

A literary bouquet

dedicated to Wolfgang Biesterfeld

- scholar, musician and philosopher -

ex laetitia sit

In a chapter titled "Genre and Real Life in Latin Poetry" Jasper Griffin states in 1986: “As long as poetry has existed, men have wondered and argued about its relationship to reality. The Muses, meeting Hesiod beneath Mount Helicon, told him that they knew how to tell many lies that sounded like truth; Solon and Pindar echo the chastening refrain, and Plato and Aristotle are concerned to find new answers to the hoary problem.",

As an ancient historian I mostly work in my field of research with records and texts that represent the relics of hard life conditions in the past, reports that show the devotions to law, administration and rule - even the practical side of life.

When I attended the gymnasium mid of the 70ties of the last century, now forty years ago, ancient Greek language was taught from perspective of philosophy, poetry and high moral standards, and Latin language was treated from the perspective of practical life management. In the same morning at school we sat one hour next to Plato or we met Sappho on her isle, and an hour later we were sent on command between Caesar's fully equipped legionary troops on their muddy way to fight the Northern 


\section{Lyric poetry as seen from an interdisciplinary}

barbaric Celtic tribes. We became like victims of the elaborate propaganda in style of Horace's carmen 1,37, courteous poetry who made us believe Cleopatra being a "fatale monstrum", a perspective that ingeniously was contradicted by Ahmed Etman's theatre play "Cleopatra worships peace" 3 . Later at University things turned to another direction: ancient Greeks' management competitions on diplomatic level became the subject of my dissertation ${ }^{4}$, and after Roman soldiers' life also unveiled a civic side, we met Latin poetry in a more than touching way: grave inscriptions written in Latin but taken from a Greek example, chiseled into the tombstones far away from the Mediterranean homeland and set by an unnamed heir. And not far from that provincial place we admired the excavation of one of the biggest Roman theatres north of the Alps in Moguntiacum (Mainz/Germany). ${ }^{5}$ What subject of performance could be of interest for the rough soldiers and the simple civilians to take their place at one of the 12.000 seats in front of the stage? Was it only the memorial rite celebration for late prince Drusus, whose mother was addressed by a poem of consolation, the text composed by an author close to the poetic circle of Ovid ? ${ }^{6}$

Such facts turned my perspective to understand that people of that time talk to us by an intriguing intensity of their self-consciousness "traveler, wait, stand here and notice what we have to tell you..."

And finally, about 2000 years after the composers of those lines passed away, we are still listening to the whisper of the ancient time, we meet each other in Aegyptus, the land of poetic maat, in order to perform a conference attempting to memorize about that what we hope to know about them. We ask each other: "Do you remember Andromache's fate?" or "What is new about Pindar's ode?" Is it more dangerous for a traveler of time to follow Homer on the battlefield next to Ilion, or is it more 


\section{Gabriele ZIETHEN}

dangerous to struggle for surviving the nightly rumor in Rome's streets, to escape Nero's money-hunters, to turn away in the last moment from the burning collapse of the houses, to avoid traffic accidents close to Trajan's market area, to reach out for the daily livestock, for a slice of bread or a piece of rural cabbage that we need for a simple meal? - Shortly to say how long will we have the energy to stand worthy Iuvenal's acid satirical voice? Anyhow, as ever we try to find an answer for that questions we can be sure that also in our life we can find a poetic sound that will help us to translate and to interpret what we are reading in the books and in our papers.

We all need poems. Even the avaricious investment banker, who calculates his life by multiplication of the percentage - English language has no words of its own to describe such illness, because already the Romans named such fate by its true character: he is the miser because he is avaricious. In case this homo miser et avarus opens his daily newspaper he will find a small greeting of the true life when reading the stock-exchange and mortgage news: suddenly between all the ratings and evaluations the tender and simple words of a small poem slip on his desk, placed by a clever editor in order to memorize the financial reader, grasping for his heart: stop, do not forget that you are still a human being - remember your soul - animam tuam memento!

To be engaged in poetry needs a time of muse, a brake for otium in order to balance ourselves in the rough daily work procedures.

Poetry is like a walk in spring, crossing a flowering meadow, dreaming with a silent smile. With the help of only few words we can discover an ingenious reality beside the normal world. The small and detailed subjects grant a universal perspective. Even like a metal-worker who in his free time prefers to work with the polished warm wood, we are 


\section{Lyric poetry as seen from an interdisciplinary}

able to find a gentle contrast to the rough daily world conditions sharpening all our senses for the beauty of creation, whose admiration will give us energy and optimism.

In an additional way lyrics have the ability to be changed into the acid speech of the satire, the language of the rude long-eared guys who even in Antiquity became the furor of the calmly living citizens. We might quarrel with them, but we also can give them a wide berth so that they remain in their field - but we have to bear their sharp letters of insult and their put to shame ${ }^{7}$, because their insolence is the alter ego of our educated existence, they remember us of our dark sides, deeply bound in our physical nature and only chained by the fragile attempt of our personal education te hominem esse memento - remember that you are human being!

In connection with poems' pin-pointing character, poetry also can imagine social and moral standards. A peaceful living together normally is defined and framed by the written and codified law, administrative advice and bureaucratic orders. However, the unwritten law based on the traditionally spoken public opinion as learnt from Cicero's consensus universorum. They support us to balance our life with an elegant manner. It is the unspoken speech, the non-discussed agreement about the common values in our social life. In case duties and demands are too much differing from each other, the texts will change for the drama whose solutions will be discussed on the public stage - either at the law court or at the theatre's playground. In any case the importance of the texts depends from the form of its cover, the measure in style and content; it will be easy to learn by heart or to remember. And if the auditory or the reader was made to feel a support to answer his questions, he will remember for life, "yes, that's the way it is". 


\section{Gabriele ZIETHEN}

It is worth to mention that even in our time modern poetry returns to adapt the formal ideas of their antique predecessors.

Either we take for example Joseph Brodsky's "Letter to the Roman Friend" " which is inspired by Roman author Martial or we accompany Durs Grünbein's Juvenal on his sleepless walk through Rome9': both are looking for the ruins - once and now.

Joseph Brodsky (1950-1996), who in 1987 received the Nobel Prize for Literature, cites in his poem composed in the year 1972:

"Here, we've covered more than half of our life span As an old slave, by the tavern, has just said it, «Turning back, we look but only see old ruins».

Surely, his view is barbaric, but yet candid." 10

Durs Grünbein states that Juvenal's satires are like a folder of warrants of arrest, a movie script ${ }^{11}$ at all. And we remember the Latin citations in Federico Fellini's movie Satyricon in 1969 after the text of Titus Petronius Arbiter mid of the 1 st century C.E. ${ }^{12}$

In a special way Durs Grünbein likes to enlighten the eternal world of values and peace ${ }^{13}$ which are situated in a world of ruins, he compares in his essay titled "Vulcan and Poem" the fate of Pompeii with the city of Dresden. Durs Grünbein, born in 1962 in Dresden, imagines the ruins of Pompeii ${ }^{14}$; and he compared the place with the bombed wreck at river Elbe ("Barockwrack an der Elbe") 15 .

Both Brodsky and Grünbein reject to follow a perspective to antiquity as we, for example, know it from the $19^{\text {th }}$ century. They ask for the meaning in daily life, they choice the vain of human life for theme, and they reflect about the mistakes of the literary heroes: Dido's hopeless vision about the destruction of Carthage is of more interest than Aeneas' expedition, as Joseph Brodsky wrote in "Dido and Aeneas" (1969). ${ }^{16}$ In a 
Lyric poetry as seen from an interdisciplinary

similar way Durs Grünbein asked for the mistakes in education projects: why failed L. Annaius Seneca, the famous philosopher, when he educated Nero? Was Seneca's key word "otium", the summary of "clementia", changed into "vanitas", and became the word "otium" the credo of fanaticism just when the author had to face the intriguing reality that he had taught the wrong student? ${ }^{17}$ Such questions research for the reason of that hopeless inability of correcting mistakes far away from any philosophical proofs $^{18}$ or morals: "Even after the first assassinations had happened, applause seemed to be the most useful pedagogic measure" ("Selbst nach den ersten paar Morden schien Beifall die geeignetste pädagogische Maßnahme"). ${ }^{19}$

With such brief examples we like to imagine that it is of great importance to develop the subjects of ancient authors and that we have to modify their perspectives when observing our time. We have to imagine a critical distance to the subject and we have to teach our students all options to find out an individual access to the texts.

This means in the same way that in modern theatre-play adaptions the questions of our time should be discussed and that we should answer frivol satires' attacks with the impudent sentence of the cynic philosophers. If someone comes and tells us "the water is running on high the mountain" the answer could be "yes, I already drunk it on the top".

From practical side we should take into consideration to encourage our students for creative writing, not only to summarize the ancient records by their written projects at the end of the term, but to do more in case to continue the plot. This exercise will evoke good writers.

We could propose our students to write an answer to Medea, to define an order of discipline for Plautus' miles gloriosus, and they could manage a social program for the parasitus and his aulularia. 


\section{Gabriele ZIETHEN}

If we entered a huge skyscraper building in a city of our time, we should meet many of these desperate characters with their typical problems, the simple situations of life and talks, chatting and fama. Working with literature comes close to social working competence - within the world of our books we are like such social street workers.

But it depends from our imagination how we could find the best form. In case we watch two old persons, a lady and a man, who quarrel and nerve each other about the quality of the silver spoons on their rich table, we can write a comedy titled "The spoons", or we can write a poem titled "The subjects of old age". One text written for the general situation, the other one because of patience and love - the old couple could be our parents.

And after we have enjoyed in this or that way the applause granted to us by our auditory we leave the place to the garden looking for Catullus' birds in carmen 2: "passer, deliciae mea puellae..." sparrows, you joy of my girl..."

However, what would happen if Lesbia's bird-cage was empty, the sweetest friends fired from Aphrodite's service, unemployed sparrows buzzing about here and there...? $?^{20}$

We could feed them with the fodder of our research...

Poems - the delicious joy of educated individuals. ${ }^{21}$ 


\section{Lyric poetry as seen from an interdisciplinary}

\section{Notes:}

1 Griffin 1986, 48-64, esp. 48 (citation).

2 Clauss 2002, 104-109; Schäfer 2006, 185-187, 251, 269-271.

3 Amal Aly Mazhar states with the introduction to Etman 2002, 9:"'In both content and dramatic structure, Etman's play is a clear case in point of the merging of, and the dialogue, not the clash between different cultures and civilizations."

4 Ziethen 1994.

5 Rupprecht 2010, 41-44; Gogräfe 2013, 59-61. For detailed collection of archaeological materials, ancient records and bibliography see http://www.theatrum.de/mainz.html <27.04.2015>.

6 Rupprecht 1982; Schoonhoven 1992; Amat 1997.

7 Grünbein 1999, 9-48.

8 http://www.poemhunter.com/best-poems/joseph-brodsky/letters-to-theroman-friend/ <23.01.2015>]

9 D. Grünbein, Schlaflos in Rom, in: Grünbein 2005, 328-368.

10 J. Brodsky, Letters to the Roman friend, paragraph 11, English translation cited after http://www.poemhunter.com/best-poems/josephbrodsky/letters-to-the-roman-friend/ <23.01.2015>. - German version titled "Briefe an einen römischen Freund (aus Martial)" in: Brodsky 2006, 70sqq.

11 Grünbein 2005, 337 „An den Satiren hätten wir jene Aktensammlung, die sie alle im Steckbrief konserviert, das ausführliche Drehbuch für einen Kostümfilm mit dem Titel „Schlaflos in Rom“. 


\section{Gabriele ZIETHEN}

12 http://de.wikipedia.org/wiki/Fellinis_Satyricon <26.02.2015>; Movie at YouTube: https://www.youtube.com/watch?v=j0L-iJGFRzE $<26.02 .3015>$

13 Interview in: Gross 2011, 222-240, esp. 227.

14 Grünbein 2006, 892-896, esp. 895.

15 D. Grünbein, Kurzer Bericht an eine Akademie. Vortrag anläßlich der Zuwahl in die Deutsche Akademie für Sprache und Dichtung, 20. Oktober 1995), in: Grünbein 2005: 11-14, esp. 12 (citation).

16 Joseph Brodsky, Dido und Äneas, in: Brodsky 2006, 42.

17 Durs Grünbein, Im Namen der Extreme, in: Grünbein 2005, 369-392, esp. 370sq., 392.

18 Cf. Biesterfeld 1970, 26-29, 69, 82. I greatly thank Prof. Dr. Wolfgang Biesterfeld (Kiel) for our inspiring talks on this topic - Cairo, March 2015.

19 Durs Grünbein, Im Namen der Extreme, in: Grünbein 2005, 392.

20 Cf. Durs Grünbein, Nach den Fragmenten, in: Braun 2002, 4-18, esp. 11.

21 The author thanks Prof. Dr. Efim A. Rezvan (Saint Petersburg), and Gerhard Humberg, PHK i. R. (Worms), for their creative ideas and individual perspectives about the meaning of poetry in our life.

\section{Selected literature}

Amat, J. 1997 (ed.). Consolation à Livie. Texte établi et trad. par Jacqueline Amat. Collection des universités de France 342. Paris. 


\section{Lyric poetry as seen from an interdisciplinary}

Biesterfeld, W. 1970, Der platonische Mythos des Er (Politeia 614 b- 621 d). Versuch einer Interpretation und Studien zum Problem östlicher Parallelen. Diss. Westfälische Wilhelms-Universität zu Münster (Westf.).

Braun, M. 2002. „Vom Rand her verlöschen die Bilder“. Zu Durs Grünbeins Lyrik und Poetik des Fragments. Text und Kritik. Zeitschrift für Literatur 153, I/02, 2002: 4-18.

Brodsky, J. 2006. Brief in die Oase. Hundert Gedichte herausgegeben von Ralph Dudi. München, Wien.

Clauss, M. 2002. Kleopatra. München, 3rd ed.

Dumont, F. (ed.) 2010. Mainz. Menschen - Bauten - Ereignisse. Eine Stadtgeschichte. Mainz.

Etman, A. 2002. Cleopatra worships Peace, translated and introduced by A. A. Mazhar. Prism Literary Series 12. Cairo, Dar Al-Kuttub Registration:1924/2002.

Gogräfe, R. 2013. Theater im römischen Reich. Bühne für Schauspieler, die Feiern des Imperiums und Sponsoren des Reiches. Mainz.

Griffin, J. 1986. Latin poets and Roman Life. Chapel Hill/N.C. (= London 1985).

Gross, M. 2011. Bruch und Erinnerung. Durs Grünbeins Poetik. In den Straßen Roms. Ein Gespräch mit Durs Grünbein. Berlin.

Grünbein, D. 1999. Nach den Satiren. Gedichte. Frankfurt am Main.

Grünbein, D. 2005. Antike Dispositionen. Aufsätze. Frankfurt am Main.

Grünbein, D. 2006. Vulkan und Gedicht, in: Der Kanon der Deutschen Literatur. Essay, Bd. 5. Max Frisch bis Durs Grünbein. Frankfurt am Main, Leipzig.

Rupprecht, G. 2010. Die älteste Theaterstadt Deutschlands, in: Dumont 2010, 41-44 


\section{Gabriele ZIETHEN}

Rupprecht, H. (ed.) 1982. Consolatio ad Liviam. Trostgedicht für Livia. Pseudoovidiana 2. Mitterfels.

Schäfer, Chr. 2006. Kleopatra. Darmstadt.

Schoonhoven, H. (ed.) 1992. The Pseudo-Ovidian "Ad Liviam de morteDrusi" (Consolatio ad Liviam, Epicedium Drusi); a critical text with introduction and commentary. Groningen.

Ziethen, G. 1994. Gesandte vor Kaiser und Senat. Studien zum römischen Gesandtschaftswesen zwischen 30 v.Chr. und 117 n. Chr. Pharos. Studien zur griechisch-römischen Antike II (Diss. Johannes Gutenberg-Universität, Mainz 1991 = St. Katharinen 1994.

\section{Internet sources}

Brodsky, J.: http://www.poemhunter.com/best-poems/joseph-brodsky /letters- to-the-roman-friend/ $<23.01 .2015\rangle$

Fellini, Satyricon: http://de.wikipedia.org/wiki/Fellinis_Satyricon $<26.02 .2015>$

Fellini, Satyricon on YouTube: https://www.youtube.com/watch?v=j0LiJGFRzE <26.02.3015>

Roman theatre in Mogontiacum/Mainz (Germany): http://www.theatrum. de/mainz.html <27.04.2015>

\section{Author's address:}

Dr. phil. Gabriele Ziethen

E-Mail: ziethen-aksum@t-online.de |g.ziethen@gmx.de

Internet: http://www.gabrieleziethen.de 